\title{
PENGEMBANGAN BUKU AJAR FISIKA BERBASIS MULTIMEDIA INTERAKTIF UNTUK PEMBELAJARAN SISWA R-SMA-BI KELAS X SEMESTER 1
}

\author{
Asrizal, Putri Handayani, Prima Desinda \\ Jurusan Fisika FMIPA Universitas Negeri Padang
}

Asrizal_unp@yahoo.com

\begin{abstract}
ABSTRAK
Buku ajar fisika berbasis multimedia interaktif merupakan suatu alternatif sumber belajar yang dapat digunakan untuk mendukung proses pembelajaran pada R-SMA-BI. Pengembangan buku ajar ini perlu dilakukan untuk menerapkan sumber belajar berbasis ICT dalam pembelajaran. Tujuan penelitian adalah untuk menentukan validitas, kepraktisan, dan keefektifan dari produk dalam bentuk buku ajar. Tipe penelitian yang dilakukan adalah penelitian dan pengembangan (R\&D) yaitu suatu metode penelitian yang digunakan untuk menghasilkan suatu produk tertentu dan menguji keefektifan dari produk tersebut. Dalam penelitian ini digunakan enam langkah $R \& D$ yaitu mengenal potensi dan masalah, mengumpulkan informasi, merancang produk, memvalidasi rancangan, merevisi rancangan, dan menguji coba produk. Instrumen yang digunakan untuk mengumpulkan data yaitu lembaran penilaian validasi, lembaran observasi, dan tes hasil belajar. Data dianalisis menggunakan statistik deskriptif, metoda grafik, dan uji perbandingan rata-rata. Dari analisis data dapat dikemukan empat hasil penelitian ini. Pertama, buku ajar fisika berbasis multimedia interaktif terdiri dari lima bab yaitu pengukuran besaran fisika, penjumlahan vektor, gerak lurus, gerak melingkar, dan hukum Newton pada masing-masing bab dilengkapi gambar, video, dan animasi. Kedua, buku ajar berbasis multimedia interaktif praktis digunakan dalam pembelajaran menurut standar proses dengan nilai rata-rata kepraktisan 93,75. Ketiga, buku ajar berbasis multimedia interaktif efektif digunakan dalam pembelajaran menurut standar proses. Keempat, penggunaan buku ajar berbasis multimedia interaktif memberikan pengaruh yang berarti terhadap hasil belajar siswa R-SMA-BI kelas X.
\end{abstract}

Kata kunci: buku ajar, multimedia interaktif, validitas, kepraktisan, keefektifan

\section{PENDAHULUAN}

Era globalisasi telah memasuki dan mempengaruhi dunia pendidikan. Era ini menuntut sekolah untuk mampu melakukan berbagai upaya untuk menciptakan lulusan yang berdaya saing global (Eddy, K: 2006). Lulusan seharusnya harus mampu mengembangkan pengetahuan dan keterampilan yang memadai dan mampu berkomunikasi dengan bangsa lain di dunia agar bisa eksis dalam kehidupan.

Dengan dasar ini pemerintah melalui Derektorat Pendidikan Menengah Umum mengembangkan sekolah bertaraf internasional (SBI). Sebagai dasar hukum SBI adalah UU nomor 20 tahun 2003, pasal 50 ayat 3 yang menyatakan bahwa "Pemerintah dan/ atau Pemerintah daerah menyelenggarakan sekurang-kurangnya satu satuan pendidikan yang bertaraf internasional". Pendidikan bertaraf internasional adalah pendidikan yang diselenggarakan setelah memenuhi Standar Nasional Pendidikan (SNP) dan diperkaya dengan standar pendidikan negara maju. Tujuan pendidikan ini adalah untuk acuan kualitas pendidikan untuk meningkatkan kualitas dan daya saing baik di tingkat regional maupun internasional (Ari, P: 2011).

Salah-satu upaya yang telah dilakukan untuk mengimpelentasikan UU ini adalah melalui Rintisan SMA Bertaraf Internasional (R-SMA-BI). R-SMA-BI merupakan SMA Nasional 
yang telah memenuhi seluruh standar nasional pendidikan, menerapkan sistem kredit semester, dan dalam proses menuju SMA bertaraf internasional (Sungkowo: 2009). Ada beberapa indikator kinerja kunci tambahan sebagai pengayaan pada R-SMA-BI antara lain guru mampu menerapkan pembelajaran dengan bahasa pengantar Inggris secara efektif dan menggunakan sumber belajar berbasis ICT untuk mendukung proses pembelajaran.

Berdasarkan hasil pengamatan peneliti pada kegiatan in house training dan observasi kelas ternyata guru fisika di SMAN Sumatera Barat masih mengalami kesulitan dalam menggunakan bahasa Inggris sebagai pengantar dalam pembelajaran fisika. Sebagian mereka telah menyiapkan silabus dan RPP dalam bahasa Inggris, memiliki buku teks berbahasa Inggris, media presentasi berbahasa Inggris, namun belum dapat menerapkan bahasa Inggris dalam pembelajaran fisika secara efektif. Disamping itu, ditemukan pula adanya keterbatasan guru dalam menggunakan sumber belajar berbasis ICT untuk mendukung pembelajaran.

Padahal tes fisika yang diberikan kepada siswa ditulis dalam bahasa Inggris. Akibatnya banyak siswa yang mengalami kesulitan menjawab tes fisika dalam bahasa Inggris. Dari hasil wawancara peneliti dengan guru fisika, diketahui nilai fisika siswa yang di tes dalam bahasa Inggris lebih rendah dari yang tes dalam bahasa Indonesia.

Permasalahan ini terjadi karena pesan materi pembelajaran baik berupa pengertian, konsep, hukum, teori dan sebagainya yang disampaikan guru berbahasa Inggris kurang dapat diterima dengan baik oleh siswa. Komunikasi akan berjalan dengan baik dan lancar apabila terdapat kesesuaian antara penyampai pesan dan penerima pesan. Untuk itu diperlukan suatu media pembelajaran yang dapat digunakan untuk membantu menyampaikan informasi dari guru kepada siswa.

Salah satu alternatif untuk mengatasi permasalahan ini adalah mengembangkan dan memanfaatkan sumber belajar berkualitas yang dapat digunakan sebagai media oleh guru dan sumber belajar bagi siswa untuk mengkontruksi pengetahuan fisika dalam bahasa Inggris. Dengan kemajuan teknologi pada saat ini, pengembangan bahan ajar berbasis multimedia memungkinkan guru untuk membuat pembelajaran lebih menarik dan lebih fleksibel.

Buku ajar merupakan salah satu jenis bahan ajar yang dapat dikembangkan. Buku ajar adalah buku yang disusun untuk kepentingan proses pembelajaran baik yang bersumber dari hasil-hasil penelitian atau hasil dari sebuah pemikiran tentang sesuatu atau kajian bidang tertentu yang kemudian dirumuskan menjadi bahan pembelajaran. (Zona P: 2011). Buku ajar menyediakan fasilitas bagi kegiatan belajar mandiri, baik tentang substansinya maupun tentang penyajiannya. Penggunaan buku ajar merupakan bagian dari budaya buku, yang menjadi salah satu tanda masyarakat maju. Dipandang dari proses pembelajaran, buku ajar mempunyai peran penting. Jika tujuan pembelajaran adalah untuk menjadikan siswa memiliki berbagai kompetensi, maka perancangan buku ajar harus memasukkan sejumlah prinsip yang dapat meningkatkan kompetensi yang hendak dimiliki siswa (Tuty H, 2011).

Buku ajar merupakan salah satu sarana penting untuk mencapai keberhasilan proses pembelajaran. Dengan adanya buku ajar akan membantu siswa dalam memahami dan menguasai tujuan yang akan dicapai dalam mata pelajaran yang ditempuhnya. Buku ini akan membimbing dan mengarahkan siswa dalam menguasai kompetensi yang diharapkan di dalam menempuh suatu mata pelajaran. Buku merupakan sebuah media pembelajaran yang sangat fundamental. Dalam pembelajaran, buku tidak hanya berperan sebagai transfer ilmu pengetahuan tetapi juga sumber inspirasi dan motivasi (Daniel S, 2011). 
Sebagai bagian dari bahan ajar, buku ajar juga merupakan satu kesatuan unit pembelajaran yang berisi informasi, pembahasan, dan evaluasi. Bila buku ajar tersusun secara sistematis akan mempermudah siswa dalam mempelajari materi sehingga mendukung ketercapaian tujuan pembelajaran. Untuk itu, buku ajar harus disusun secara sistematis, menarik, aspek keterbacaannya tinggi, mudah dicerna, dan mematuhi aturan penulisan yang berlaku. Secara umum naskah buku ajar yang baik, mencakup unusur-unsur sebagai berikut: (1) Prakata, (2) Daftar Isi, (3) Batang Tubuh yang terdiri dari bab atau bagian beserta Tujuan Instruksionalnya, (4) Daftar Pustaka, (5) Glosarium, dan (6) Indeks (sebaiknya) (Amin Y, 2011).

Penggunaan multimedia interaktif dalam suatu buku ajar mendorong motivasi dan keaktifan siswa dalam belajar. Multimedia dapat diartikan sebagai lebih dari satu media. Ia bisa berupa kombinasi antara teks, grafik, animasi, suara dan video. Perpaduan dan kombinasi dua atau lebih jenis media ditekankan kepada kendali komputer sebagai penggerak keseluruhan gabungan media itu. Umumnya multimedia yang dikenal dewasa ini adalah berbagai macam kombinasi grafik, teks, suara, video, dan animasi. Penggabungan ini merupakan satu kesatuan yang secara bersama-sama menampilkan informasi, pesan, atau isi pelajaran (Azhar A: 2003).

Pengertian lain dari multimedia adalah media yang menggabungkan dua unsur atau lebih media yang terdiri dari teks, grafis, gambar, foto, audio, video dan animasi secara terintegrasi. Secara umum multimedia terbagi menjadi dua kategori, yaitu: multimedia linier dan multimedia interaktif. Multimedia linear adalah suatu multimedia yang tidak dilengkapi dengan alat pengontrol apapun yang dapat dioperasikan oleh pengguna sehingga berjalan secara berurutam seperti TV dan film. Multimedia interaktif adalah suatu multimedia yang dilengkapi dengan alat pengontrol yang dapat dioperasikan oleh pengguna, sehingga pengguna dapat memilih apa yang dikehendaki untuk proses selanjutnya. Contohnya adalah multimedia pembelajaran interaktif, aplikasi game, dll (Asti A, 2010). Penggunaan komputer untuk menampilkan dan mengkombinasikan text, graphics, audio, video dan animasi dengan menggunakan links dan tools yang memungkinkan pemakai untuk melakukan navigasi, berinteraksi, membuat, dan berkomunikasi atau berkolaborasi.

Secara umum manfaat multimedia yang dapat diperoleh adalah proses pembelajaran lebih menarik, lebih interaktif, jumlah waktu mengajar dapat dikurangi, kualitas belajar siswa dapat ditingkatkan dan proses pembelajaran dapat dilakukan di mana dan kapan saja, serta sikap belajar siswa dapat ditingkatkan (Ivandri, 2011). Hal ini dapat terjadi karena multimedia memiliki beberapa keunggulan bila dibandingkan media-media lainnya seperti buku, audio, video atau televisi. Keunggulan paling menonjol yang dimiliki multimedia adalah interaktivitas. Interaktivitas nyata disini adalah interaktivitas yang melibatkan fisik dan mental dari pengguna saat mencoba program multimedia (Gatot P, 2008). Keunggulan lain dari teknologi multimedia adalah menarik perhatian, karena aplikasi ini memiliki teknik penyajian yang menarik; media alternatif dalam penyampaian pesan, karena diperkuat dengan teks, suara, gambar, video, dan animasi; dan meningkatkan kualitas penyampaian informasi (Eko N, 2009).

Materi yang berhubungan dengan sains adalah materi yang sangat cocok untuk dijelaskan melalui multimedia. Hal ini berkaitan dengan sifat dari materi sains sendiri yang banyak berhubungan dengan penjelasan suatu fenomena, proses, dan hal-hal lain yang dinamis (Gatot P, 2008). Penggunaan multimedia dalam pembelajaran akan dapat meningkatkan penguasaan siswa. Alasannya adalah orang mampu mengingat $20 \%$ dari yang dilihat, mampu mengingat 30\% dari yang didengar, mampu mengingat 50\% dari yang didengar dan 
dilihat, serta mampu mengingat $60 \%$ dari yang didengar, dilihat dan dilakukan.Penggunaan multimedia interaktif dengan menampilkan fitur-fitur akan dapat dijadikan sarana komunikasi visual (Sri R, 2011).

Mengingat pentingnya buku ajar fisika berbasis multimedia interaktif dalam bahasa Inggris untuk pembelajaran siswa R-SMA-BI maka peneliti tertarik untuk melakukan penelitian. Sebagai judul penelitian yaitu "Pengembangan Buku Ajar Fisika Berbasis Multimedia Interaktif untuk Pembelajaran Siswa R-SMA-BI Kelas X Semester 1". Ada empat tujuan dari penelitian ini yaitu: untuk mendeskripsikan desain buku ajar, menentukan validitas desain buku ajar, menentukan kepraktisan penggunaan buku ajar dalam pembelajaran, dan menentukan keefektifan penggunaan buku ajar dalam pembelajaran.

\section{METODE PENELITIAN}

Jenis penelitian yang akan dilakukan adalah Research and Development (R\&D). Sugiyono (2006) mengemukakan pengertian R\&D adalah metode penelitian yang digunakan untuk menghasilkan produk tertentu, dan menguji keefektifan produk tersebut. Disisi lain menurut Nana, S.S (2006) R\&D adalah suatu proses atau langkah-langkah untuk mengembangkan suatu produk baru atau menyempurnakan produk yang telah ada, yang dapat dipertanggung jawabkan. Produk tersebut tidak selalu berbentuk perangkat keras (hardware) seperti buku, alat bantu pembelajaran di kelas maupun di laboratorium, tetapi juga bisa berupa perangkat lunak (software) seperti program komputer untuk pengolahan data, pembelajaran di kelas, laboratorium, model pendidikan dan pembelajaran, dan evaluasi. Berarti produk merupakan bagian yang penting pada pada penelitian ini.

Pada kegiatan uji coba penggunaan buku ajar fisika berbasis multimedia interaktif digunakan dua desain eksperimen. Pertama, desain eksperimen dengan cara membandingkan keadaan sebelum dan keadaan sesudah (before-after) diberi perlakuan. Kedua, desain eksperimen dengan kelompok pembanding. Model eksperimen ini diperlihatkan seperti pada Gambar 1:

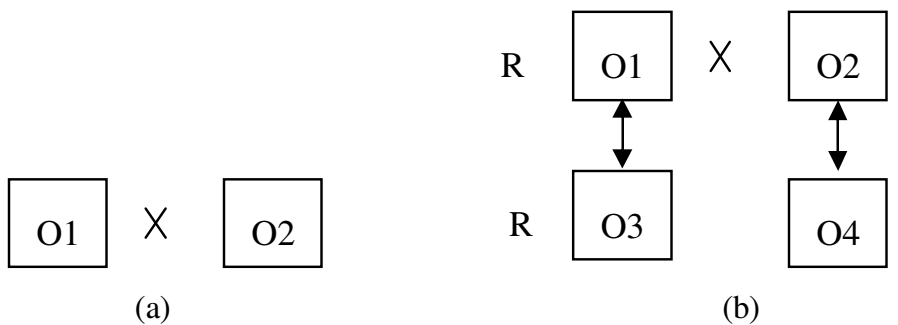

Gambar 1 (a). Desain Eksperimen Sebelum-Sesudah (b). Desain Eksperimen Dengan Kelompok Kontrol

Pada desain eksperimen sebelum-sesudah, $\mathrm{O}_{1}$ adalah nilai sebelum perlakuan, sedangkan $\mathrm{O}_{2}$ adalah nilai sesudah perlakuan. Eksperimen dilakukan dengan membandingkan hasil observasi $\mathrm{O}_{1}$ dan $\mathrm{O}_{2}$. Efektifitas pemberian perlakuan dapat diukur dengan cara membandingkan nilai $\mathrm{O}_{2}$ dengan $\mathrm{O}_{1}$. Bila nilai $\mathrm{O}_{2}$ lebih besar dari pada $\mathrm{O}_{1}$, maka dapat dikatakan perlakuan tersebut efektif. Disisi lain pada desain eskperimen dengan kelompok kontrol, $\mathrm{O}_{1}$ adalah nilai awal kelompok eksperimen dan $\mathrm{O}_{3}$ adalah adalah nilai awal kelompok kontrol. Kedua kelompok sampel dipilih secara random (R) dan memiliki kemampuan awal yang sama. Setelah perlakuan diberikan diberikan tes akhir sehingga $\mathrm{O}_{2}$ adalah nilai akhir kelompok eksperimen dan $\mathrm{O}_{4}$ adalah nilai akhir kelompok kontrol. 
Efektivitas penggunaan buku ajar berbasis multimedia interaktif ditentukan dengan membandingkan hasil belajar kedua kelompok siswa.

Instrumen pengumpul data penelitian pada tahun kedua ada tiga macam yaitu: lembaran penilaian validitas tenaga ahli, lembaran uji kepraktisan, dan lembaran tes hasil hasil belajar. Lembaran penilaian validitas digunakan untuk menilai kevalidan dari desain buku ajar fisika menurut pemikiran rasional. Lembaran uji kepraktisan digunakan untuk menentukan keterlaksanaan penggunaan buku ajar fisika berbasis multimedia interaktif dalam pembelajaran menurut standar proses. Lembaran tes hasil belajar digunakan untuk menentukan efektivitas penggunaan buku ajar fisika berbasis multimedia interaktif dalam pembelajaran menurut standar proses.

Dari data uji coba terbatas dilakukan dua analisis terhadap penggunaan buku ajar fisika berbasis multimedia interaktif dalam pembelajaran yaitu analisis kepraktisan dan analisis keefektifan. Analisis kepraktisan dilakukan untuk mengetahui apakah produk dalam bentuk buku ajar yang dibuat memenuhi kriteria kepraktisan ditentukan berdasarkan keterlaksanaan buku ajar dalam proses pembelajaran. Analisis keefektifan dilakukan untuk mengetahui apakah buku ajar fisika berbasis multimedia interaktif yang dibuat memenuhi komponen kriteria keefektifan yakni tes hasil belajar.

Untuk menganalisis kepraktisan dan keefektifan penggunaan buku ajar ini digunakan teknik analisis data yang sesuai. Ada empat macam teknik analisis data yang digunakan yaitu analisis statistik deskriptif, metoda grafik, analisis regresi linear dan korelasi, dan analisis perbandingan rata-rata. Analisis deksriptif digunakan untuk mengetahui informasi lebih rinci dari satu kelompok data hasil belajar siswa. Metoda grafik digunakan untuk memberikan kesan visual tentang kepraktisan penggunaan bahan ajar dalam pembelajaran. Analisis regresi dan korelasi masing-masing digunakan untuk menentukan hubungan hasil belajar sesudah dengan sebelum perlakuan dan menentukan nilai koefisien regresi. Analisis perbandingan rata-rata digunakan untuk menentukan keefektifan penggunaan buku ajar fisika berbasis multimedia interaktif dalam pembelajaran menurut standar proses.

\section{HASIL DAN DISKUSI}

Sesuai dengan tujuan penelitian yang telah ditetapkan, secara umum ada empat hasil utama dari penelitian ini. Keempat hasil tersebut meliputi: deskripsi buku ajar fisika, hasil uji valditas buku ajar fisika, hasil uji kepraktisan penggunaan bahan ajar fisika, dan hasil uji keefektifan buku ajar fisika.

\section{Deskripsi Buku Ajar Fisika Berbasis Multimedia Interaktif}

Buku ajar físika berbasis multimedia interaktif dalam bahasa Inggris dibuat sesuai dengan desain yang telah disusun. Desain buku ajar Fisika meliputi: menu utama, sub menu, bentuk tampilan, interaktivitas, jenis dan ukuran font, dan sebagainya. Buku ajar dibuat menggunakan CMS tipe Joomla! Version 1.0. Tampilan pada home diperlihatkan pada Gambar 2a.

Home memberikan gambaran umum pada pengguna tentang buku ajar fisika berbasis multimedia dalam bahasa Inggris. Pada home pengguna dapat mengetahui menu utama pada buku ajar fisika. Menu utama buku ajar físika meliputi: home, competence, learning book, enrichment, download, and evaluation. Home juga menggambarkan dasar yang digunakan untuk menulis buku ajar yaitu standar kompetensi dan standar kompetensi. Pada buku ajar terdapat lima bab yaitu: besaran Fisika dan pengukuran, penjumlahan vektor, gerak lurus, gerak melingkar, dan hukum Newton. Pada home penulis memberikan 
motivasi kepada pengguna untuk mempelajari buku ajar dalam meningkatkan penguasaan terhadap konsep, prinsip, hukum Fisika dan aplikasinya. Terakhir, pada home pengguna dapat memberikan tanggapan terhadap buku ajar Fisika dan gambar menarik yang dapat berganti secara otomatis dalam waktu tertentu.

Menu kedua pada buku ajar fisika adalah kompetensi yang akan dicapai dalam pembelajaran. Sebelum mempelajari setiap bab diharapkan siswa perlu mempelajari standar kompetensi, kompetensi dasar, dan indikator. Tampilan menú home dan kompetensi diperlihatkan pada Gambar 2a dan Gambar 2b.

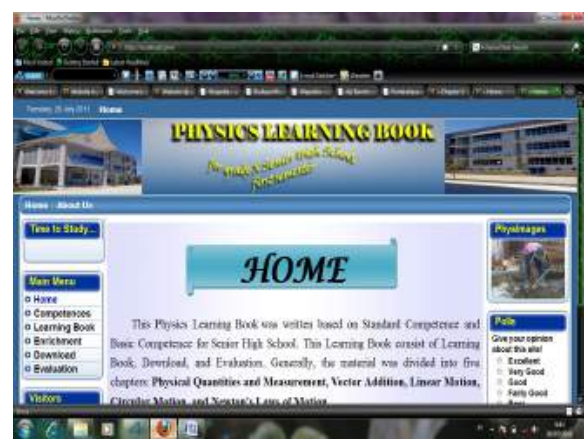

(a)

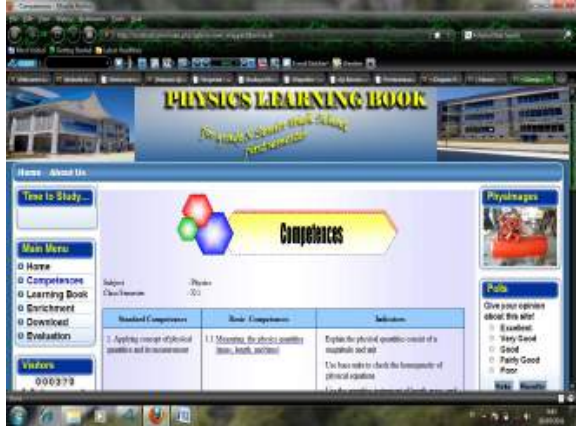

(b)

Gambar 2 (a). Tampilan Menu Home (b). Tampilan Menu Kompetensi

Pada menú buku ajar berisi konten dari sebuah buku meliputi pendahuluan, daftar isi, bab, glosary, dan indek. Dalam batang tubuh buku ajar terdapat liba lima bab. Judul setiap bab dapat dilihat pada bagian tengah. Pengguna dapat masuk ke dalam setiap bab melalui tampilan menú atau judul setiap bab. Salah satu contoh tampilan bab 3 tentang gerak lupus dan aplikasi diperlihat pada Gambar 3b

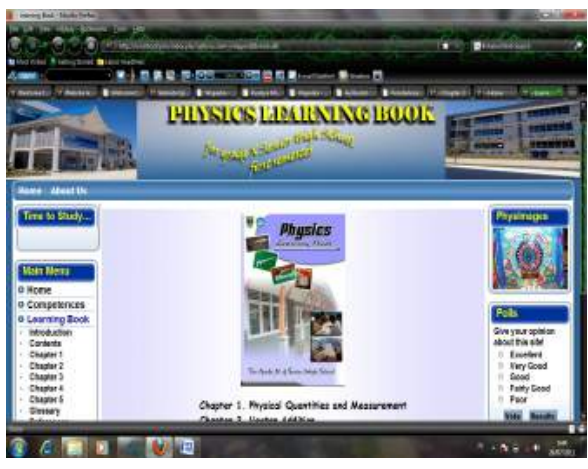

(a)

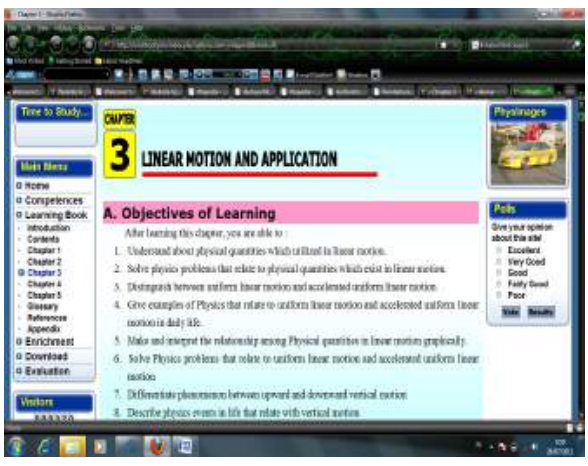

(b)

Gambar 3 (a). Tampilan Menu Pada Buku Ajar (b). Contoh Tampilan Salah Satu Bab Buku Ajar

\section{Hasil Validasi Buku Ajar Berbasis Multimedia Interaktif}

Hasil validasi desain buku ajar Fisika berbasis multimedia interaktif diperoleh dari 9 orang tenaga ahli. Tenaga ahli yang dimaksud adalah orang yang dipercaya mampu melakukan validasi terhadap buku ajar físika. Tenaga ahli yang dipilih terdiri dari 5 orang 
dosen fisika yang berpengalaman dibidang Fisika Dasar dan media pembelajaran dan 4 orang guru Físika sebagai praktisi di R-SMA-BI.

Lembaran penilaian dari dosen terdiri dari lima indikator yaitu kelayakan isi, penggunaan bahasa, penyajian pada buku, kegrafisan pada buku ajar, dan kelengkapan buku ajar. Disisi lain lembaran penilaian guru físika sebagai praktisi terdiri dari empat indikator yaitu kelayakan isi buku ajar, penyajian dalam buku ajar, manfaat buku ajar, dan peluang implementasi buku ajar. Nilai rata-rata penilaian dosen físika dan guru físika masingmasing dapat diperjhatikan pada Gambar 4a dan Gambar 4b.

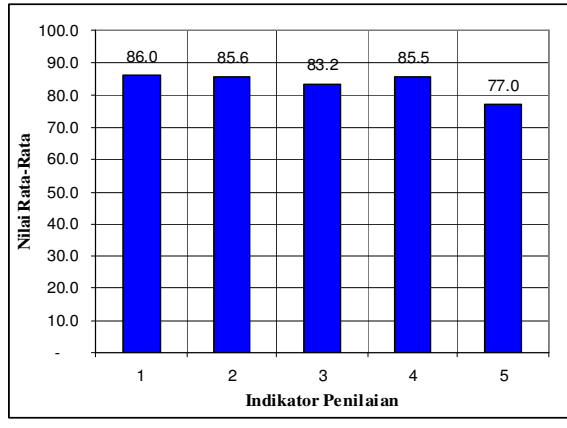

(a)

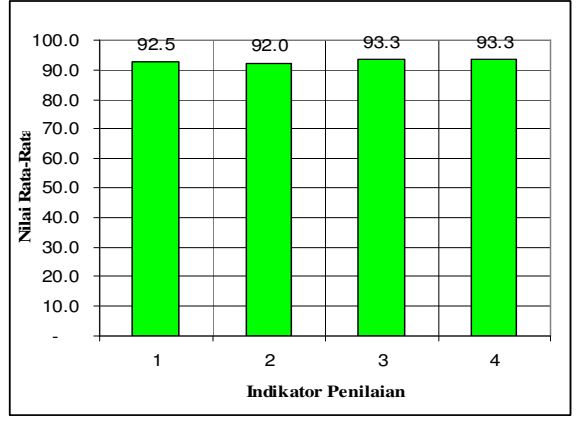

(b)

Gambar 4 (a). Nilai Validasi Rata-Rata Dosen Fisika Gambar (b). Nilai Validasi Rata-Rata Guru Fisika

Dari Gambar 4a dinyatakan nilai rata -rata hasil analisis lembar validasi dari dosen fisika. Dari grafik terlihat nilai rata-rata tertinggi hingga terendah untuk setiap indikator adalah: indikator kelayakan isi buku ajar Fisika dengan nilai 86, berada dalam kriteria sangat baik. Kategori penggunaan bahasa pada buku ajar Fisika dengan nilai 85,6. Indikator ini berada pada posisi kedua dengan kriteria sangat baik. Indikator kegrafisan buku ajar dengan nilai 85,5 berada pada posisi ketiga yang berada pada kriteria sangat baik. Kategori penyajian buku ajar elektronik Fisika dengan nilai 83,2 dengan kriteria sangat baik. Nilai rata-rata indikator terendah berada pada indikator kelengkapan buku ajar física dengan nilai 77 nilai yang berada pada kriteria baik. Dari hasil analisis lembaran validasi dari dosen dapat diungkapkan bahwa buku ajar físika berbasis multimedia interaktif adalah valid dengan nilai validitas rata-rata adalah 83,46 dari rentangan nilai rata-rata kategori adalah 77 $-86$.

Dari Gambar 4b dapat dilihat nilai rata -rata hasil analisis penilaian dari guru fisika. Dari grafik terlihat nilai rata-rata tertinggi hingga terendah untuk setiap kategori. Indikator teritinggi adalah manfaaat buku ajar elektronik fisika bagi guru dengan nilai 93,3 berada pada kriteria sangat baik. Peluang implementasi buku ajar fisika dengan nilai 93,3 berada pada kriteria sangat baik. Indikator kelayakan isi buku ajar fisika dengan nilai 92,5 berada pada kriteria sangat baik. Nilai rata-rata terendah berada pada indicator penyajian dalam buku ajar fisika dengan nilai rata-rata 92,0 yang berada pada kriteria sangat baik. Dari hasil analisis data penilaian guru fisika terhadap buku ajar fisika berbasis multimedia interaktif diperoleh nilai rata-rata 92,8 yang berada pada kriteria sangat baik.

\section{Hasil Uji Kepraktisan Bahan Ajar}

Untuk menentuk kepraktisan implementasi buku ajar físika berbasis multimedia interaktif dalam pembelajaran menurut standar proses dilakukan pengamatan terhadap keterlaksanaan 
aspek pada langkah-langkah pembelajaran. Keterlaksanaan implementasi buku ajar físika diamati selama proses pembelajaran meliputi kegiatan pendahuluan, kegiatan inti, dan kegiatan penutup. Instrumen yang digunakan dalam pengambilan data ini adalah lembaran observasi. Lembaran observasi diisi oleh observer berdasarkan aktivitas yang dilaksanakan oleh guru dalam pembelajaran menggunakan buku ajar físika. Uji kepraktisan penggunaan buku ajar físika dilakukan untuk tiga kali pertemuan sehingga rata-rata nilai setiap aspek keterlaksanaan didapatkan dengan cara menjumlahkan nilai setiap aspek keterlaksanan dan membagi dengan jumlah pertemuan. Presentase keterlaksanaan penggunaan buku ajar físika pada kegiatan pendahuluan, kegiatan inti, dan kegiatan penutup dapat diperhatikan pada Gambar 5

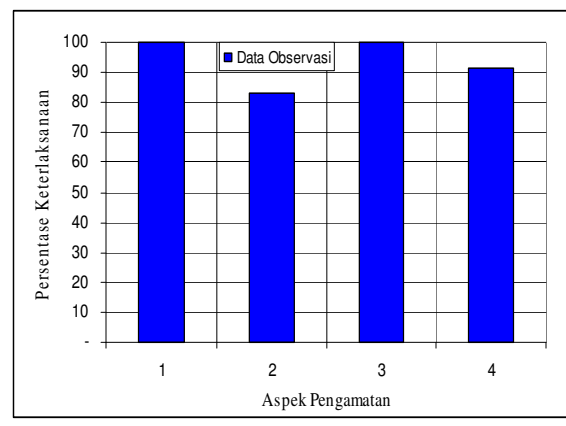

(a)

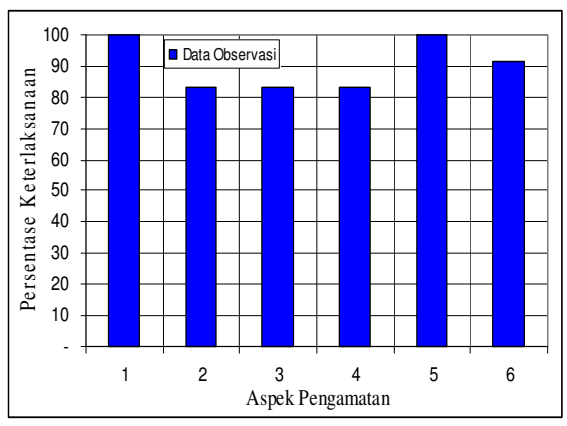

(b)

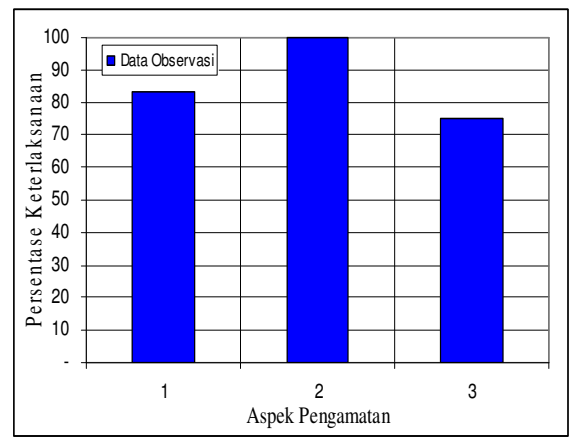

(c)

Gambar 5 (a). Keterlaksanaan Pada Kegiatan Pendahuluan (b). Keterlaksanaan Pada Kegiatan Inti (c) Keterlaksanaan Pada Kegiatan Penutup

Dari Gambar 5a dapat dilihat nilai rata-rata keterlaksanaan pada kegiatan pendahuluan. Pengamatan dalam pelaksanaan terdiri dari empat aspek yaitu: 1. Guru menyiapkan siswa untuk belajar dengan menanyakan materi yang akan dipelajari dengan nilai 100;2. Guru mereview materi pelajaran lalu yang berhubungan dengan materi pelajaran yang akan dibahas dengan tanya jawab dengan nilai 83,33; 3. Guru memotivasi siswa dengan mengajukan pertanyaan-pertanyaan yang berhubungan dengan video dan animasi yang terdapat pada buku ajar fisika dengan tanya jawab dengan nilai 100; dan 4. Guru meminta siswa menjelaskan kompetensi dan tujuan pembelajaran dengan nilai 91,7. Rata-rata keterlaksanaan buku ajar fisika ini dalam kegiatan pendahuluan adalah 93,75 yang termasuk pada kriteria sangat baik. 
Dari Gambar 5b dapat dilihat nilai rata - rata keterlaksanaan kegiatan inti. Pengamatan keterlaksanaan terdiri dari 6 aspek yaitu: 1. Guru menyuruh siswa untuk mengamati dan memikirkan peristiwa fisika melalui video dan animasi yang terdapat dalam buku ajar dengan nilai 100, 2. Guru menyampaikan materi pelajaran secara singkat menggunakan media presentasi yang terdapat dalam buku ajar disertai tanya jawab dengan nilai 83,3; 3 . Guru mengorganisasikan siswa untuk bekerja dalam kelompok mengerjakan tugas yang terdapat dalam buku ajar dengan nilai 83,3; 4. Guru membimbing siswa bekerja dalam kelompok untuk membahas latihan yang terdapat dalam buku ajar dengan nilai 83,3; 5 . Guru memilih kelompok siswa secara acak untuk mempresentasikan kerja kelompoknya dengan nilai 100; dan 6. Guru memberi umpan balik terhadap proses dan hasil kerja kelompok siswa dengan cara memberikan koreksi dan penguatan dengan nilai 91,7. Ratarata keterlaksanaan penggunaan buku ajar fisika dalam kegiatan inti adalah 90,28 yang termasuk pada kriteria sangat baik.

Dari Gambar 5c dapat dilihat nilai rata-rata keterlaksanaan dalam kegiatan inti. Pengamatan keterlaksanaan pada kegiatan penutup terdiri dari 3 aspek yaitu: 1. Guru mengarahkan siswa untuk menyimpulkan materi pembelajaran dengan nilai 83,$3 ; 2$. Guru meminta siswa untuk mempelajari materi untuk pertemuan berikutnya pada bahan ajar dengan nilai 100; dan 3. Guru memberikan pekerjaan rumah yang terdapat pada buku ajar fisika dengan nilai 75. Berdasarkan analisis yang telah dilakukan dapat dikatakan bahwa buku ajar fisika praktis digunakan dalam proses pembelajaran dengan nilai rata-rata 86,1 yang termasuk pada kriteria sangat baik.

Rata-rata keterlaksanaan buku ajar fisika berbasis multimedia interaktif dalam bahasa Inggris pada proses pembelajaran menurut standar proses didapat dengan menjumlahkan rata-rata keterlaksanaan rata-rata pertemuan kemudian dibagi dengan jumlah pertemuan. Dari hasil yang didapat diperoleh rata-rata keterlaksanaan penggunaan buku ajar fisika adalah 90,046. Angka 90,046 ini mengindikasikan bahwa penggunaan buku ajar fisika berbasis multimedia interaktif dalam pembelajaran sudah terlaksana sangat baik. Dengan demikian penggunaan buku ajar fisika berbasis multimedia interaktif dalam pembelajaran menurut standar proses adalah praktis.

\section{Hasil Uji Keefektifan Bahan Ajar}

a. Hasil Analisis Desain Eskperimen Sebelum-Sesudah

Untuk melihat keefektifan dari penggunaan buku ajar fisika dilakukan uji coba terbatas pada siswa kelas $\mathrm{X}_{6}$ R-SMA BI 1 Padang Dari penelitian yang telah dilakukan didapatkan data nilai tes awal dan tes akhir siswa. Dari hasil yang didapat kemudian dilakukan analisis validitas dan keandalan tes. Tes yang digunakan adalah memiliki tingkat validitas cukup tinggi dan keandalan yang sedang.

Untuk mendapatkan nilai $t_{\text {hitung }}$ diperlukan data berupa hasil belajar siswa sebelum menggunakan buku ajar fisika dan sesudah menggunakan buku ajar fisika. Penggunaan buku ajar ini dianggap efektif apabila $t_{\text {hitung }}$ lebih besar dari $t_{\text {tabel. }}$. Dari data jumlah siswa, nilai rata-rata, varian, standar deviasi, dan koefisien korelasi untuk tes awal dan tes akhir hasil uji perbadingan berkorelasi dengan nilai $t=16,01$. Untuk uji satu pihak dengan $n=32$ dan derajat kebebasan $(\mathrm{dk})=31$ didapatkan nilai $\mathrm{t}$ tabel pada distribusi $\mathrm{t}$ untuk taraf nyata 0,05 didapat nilai 2,698.

Dari hasil perhitungan didapatkan $t_{\text {hitung }}>t_{\text {tabel }}$ sehingga dapat dikemukakan bahwa terdapat perbedaan yang berarti antara hasil belajar siswa sebelum dan sesudah penggunaan buku ajar fisika berbasis multimedia interaktif dalam pembelajaran menurut standar proses di kelas X SMAN 1 Padang. Hal ini menunjukkan bahwa penggunaan buku ajar fisika 
berbasis multimedia interaktif adalah efektif dalam pembelajaran menurut standar proses pada siswa kelas X SMAN 1 Padang.

2. Hasil Analisis Desain Eksperimen Dengan Kelompok Kontrol

Kelompok eksperimen diberikan perlakuan penggunaan buku ajar berbasis multimedia interaktif dalam bahasa Inggris untuk enam kali pertemuan sedangkan pada kelompok kontrol tidak. Setelah diberi perlakuan pada kelompok eksperimen dan kelompok kontrol diberikan tes akhir. Jumlah siswa pada kelompok eksperimen adalah 30 orang, nilai ratarata siswa adalah 77,20, dan varian adalah 139,20. Disisi lain jumlah siswa pada kelompok kontrol adalah 28 orang, nilai rata-rata adalah 64,57, dan varian adalah 134,77. Standar deviasi gabungan dari kedua kelompok siswa adalah 11,7. Dengan menggunakan uji perbandingan rata-rata untuk data normal dan varian homogen didapatkan nilai $t_{h}=4,12$. Pada taraf nyata $\alpha=0,05$ untuk derajat kebebasan 56 dan peluang 0,975 didapatkan nilai $\mathrm{t}_{0,975}=2,01$. Karena nilai $\mathrm{t}_{\mathrm{h}}=4,12$ berarti hipotesis Ho ditolak.

Hipotesis Ho ditolak berarti terdapat perbedaan yang berarti antara hasil belajar siswa dalam pembelajaran menurut standar proses menggunakan buku ajar berbasis multimedia interaktif dalam bahasa Inggris dengan siswa yang tidak menggunakan buku ajar berbasis multimedia interaktif. Pada keadaan awal sebelum memberikan perlakuan kedua kelas siswa memiliki kemampuan yang hampir sama. Adanya perbedaan yang berarti setelah memberikan perlakuan berarti terdapat pengaruh pemberian perlakuan. Dari analisis ini dapat dikemukakan terdapat pengaruh yang berarti penggunaan buku ajar fisika berbasis multimedia interaktif dalam bahasa Inggris dalam pembelajaran menurut standar proses terhadap hasil belajar siswa R-SMA-BI kelas X di SMAN 1 Padang. Dengan demikian dapat disimpulkan bahwa penggunaan buku ajar fisika berbasis multimedia interaktif dalam bahasa Inggris juga efektif dalam pembelajaran menurut standar proses pada uji eksperimen dengan kelompok kontrol.

\section{KESIMPULAN}

Berdasarkan analisis data yang telah dilakukan dapat dikemukakan empat hasil dari penelitian ini.

1. Buku ajar fisika berbasis multimedia interaktif terdiri dari lima bab yaitu pengukuran besaran fisika, penjumlahan vektor, gerak lurus, gerak melingkar, dan hukum Newton pada masing-masing bab dilengkapi gambar, video, dan animasi

2. Desain produk buku ajar memiliki validitas yang tinggi dengan nilai rata tenaga ahli dan praktisi masing-masing 83,46 dan 92,80

3. Buku ajar berbasis multimedia interaktif praktis digunakan dalam pembelajaran menurut standar proses dengan nilai rata-rata kepraktisan 90,046

4. Buku ajar berbasis multimedia interaktif efektif digunakan dalam pembelajaran menurut standar proses

\section{UCAPAN TERIMA KASIH}

Penelitian ini merupakan penelitian kerjasama dengan mahasiswa pendidikan Fisika yang merupakan bagian dari penelitian hibah bersaing tahun 2009 dengan judul Pengembangan Bahan Ajar Elektronik Fisika Berbahasa Inggris Berbasis Multimedia Interaktif Untuk Implementasi Pembelajaran Siswa Kelas Internasional Di SMAN Sumatera Barat. Terima kasih kepada Direktorat Jenderal Pendidikan yang telah mendanai penelitian hibah bersaing. 


\section{DAFTAR PUSTAKA}

Amin Yusuf dan R Gunawan S, (2011). Pengembangan Penulisan Buku Ajar Dalam Program TOT Penulisan Karya Ilmiah Widyaswara. http://istinurhayatispdman. blogspot.com/2011/05/pengembangan-penulisan-buku-ajar-dalam.html

Ari Perwira, (2011). Sekolah Bertaraf Internasional. http://id. Ariperwira,com/ 2011/04/sekolah-bertaraf-internasional-sbi.html

Asti Amatunisan, (2010). Peranan Multimedia Dalam Pembelajaran. http://gakuseishinsetsu.wordpress.com/2010/01/06/peranan-multimediadalam-pembelajaran/

Azhar, A, (2003). Media Pembelajaran. PT RajaGrafindo Persada, Jakarta.

Daniel Saputra, dkk, (2011). Pembuatan Buku Ajar. Pusbangdik Universitas Sriwijaya, http://pusbangdik.unsri.ac.id/index.php?pilih=hal\&id=14

Eko Nugroho, (2009). Pemanfaatan Aplikasi Multimedia Sebagai Sarana Penyebarluasan Informasi dan Penyuluhan Pertanian. Pengembang Aplikasi Web dan Multimedia Pusat Data dan Informasi Pertanian -Departemen Pertanian Prosiding Seminar Nasional Himpunan Informatika Pertanian Indonesia 2009 ISBN : 978-979-95366-07.

Gatot Pramono, (2008). Pemanfaatan Multimedia Pembelajaran. Pusat Teknologi Informasi dan Komunikasi Pendidikan Departemen Pendidikan Nasional

Ivandri, (2011). Manfaat Multimedia Dalam Proses Pembelajaran. http://id.shvoong.com/social-sciences/education/2145961-manfaatmultimedia-dalam-proses-pembelajaran/

Nana, S.S, (2000). Metode Penelitian Pendidikan. Program Pascasarjana Universitas Pendidikan Indonesia dan PT Remaja Rosdakarya.

Sri Rachmawati, Dora Fatma Nurshanti . Pemanfaatan Multimedia Interaktif Untuk Menunjang Kemampuan Bekomunikasi Visual Mahasiswa. Dosen Universitas Bina Darma, Palembang, Dosen Universitas Baturaja, Kabupaten OKU: dora_sumsel@yahoo.com, http://blog.binadarma. Ac.id/dora/? p=7

Sugiyono, (2006). Metode Penelitian Pendidikan: Pendekatan Kuantitatif, Kualitatif, dan $R \& D$. Alfabeta, Bandung.

Sungkowo, (2009). Panduan Penyelenggaraan Program Rintisan SMA Bertaraf Internasional (R-SMA-BI). Departemen Pendidikan Nasional, Direktorat Pembinaan Sekolah Menengah Atas.

Tuty Hijriana, (2011). Karakteristik Buku Ajar. http://blog.unnes.ac.id /tutyhijrianapgsd/2011/04/30/karakteristik-buku-ajar/

Zona Prasko, (2011). Buku Ajar dan Bahan Ajar. http://prasxo.wordpress. com/tag/pengertian-buku-ajar/ 